\title{
Genetic and ecological differentiation between sympatric colour morphs of the common intertidal sea anemone Actinia equina
}

\author{
G. S. Haylor ${ }^{1}$, J. P. Thorpe ${ }^{1}$ and M. A. Carter $^{2}$ \\ 1 Department of Marine Biology, University of Liverpool, Port Erin, Isle of Man, United Kingdom \\ 2 Department of Biological Sciences, Portsmouth Polytechnic, King Henry I Street, Portsmouth, England
}

\begin{abstract}
The abundant intertidal sea anemone Actinia equina occurs in a variety of colour morphs of which 3 (green, red, brown) are investigated in the present work. Green anemones are known to be morphologically and behaviourally different from the other colour morphs and may be ecologically distinct; it is also known that green morphs are differentially selected by certain nudibranch predators. Differences between morphs are investigated in detail using large numbers of anemones and employing enzyme electrophoresis as criterion for genetic differentiation. The green morph has clearly different ecological preferences both with respect to mean tidal position on the shore and choice of microhabitat; it also differs significantly at 4 of the 17 enzyme loci examined. According to biochemical evidence there is little or no gene flow between sympatric populations of green and other colour morphs. It is suggested that the green Actinia should best be regarded as a separate species, and the name Actinia prasina is proposed.
\end{abstract}

\section{INTRODUCTION}

The intertidal sea anemone Actinia equina L. is very common on rocky shores around the British Isles. Its distribution extends around the Atlantic and Mediterranean coasts of Europe and North Africa (Stephenson, 1935; Schmidt, 1971; Manuel, 1981); exact geographical limits are not clear (Stephenson, 1935). Because of its abundance Actinia is also of considerable ecological importance.

The wide range of colour forms (Tugwell, 1856; Gosse, 1860) and some morphological (Cocks, 1850; Gosse, 1860; Stephenson, 1935; Schmidt, 1971; Carter and Thorpe, 1981), ecological (Teissier and Teissier, 1930; Carter and Thorpe, 1981) and reproductive (Teissier and Teissier, 1930; Carter and Thorpe, 1981) variations have resulted in much debate as to the taxonomic status of individual forms. Various colour morphs have been given specific status by earlier workers (Templeton, 1836; Dalyell, 1848; Cocks, 1850; Tugwell, 1856; Milne-Edwards, 1857). Stephenson (1935) in his monograph restricts the number of varieties to 2, Actinia equina var. mesembryanthemum and $A$. equina var. fragacea. A later review by Schmidt (1971), based on size and distribution of nematocyst types and number of complete septal cycles, divides $A$. equina into 4 subspecies, 3 of which are geographically replacing. One of these latter subspecies, Schmidt names $A$. equina equina which is equivalent to the var. mesembryanthemum of Stephenson (1935). Another, $A$. equina fragacea, is equivalent to Stephenson's var. fragacea.

These 2 varieties have recently been found to show distinct differences in relative shore distributions, weight, methods of reproduction and isozyme patterns and are no longer considered conspecific (Carter and Thorpe, 1981; Manuel, 1981). Manuel (1981) describes Stephenson's (1935) Actinia equina var. fragacea as $A$. fragacea Tugwell and $A$. equina var. mesembryanthemum therefore becomes simply $A$. equina.

The taxonomic status of various morphotypes of Actinia equina is open to some doubt. In particular the green colour morph shows certain features which distinguish it from other $A$. equina. Apart from the colour there are differences between the green and other colour morphs in internal morphology, intertidal distribution and behaviour. Schmidt (1971) describes the arrangement of the internal septa in the red and brown colour morphs (his $A$. equina equina form I) as showing regular radial hexamery with always 192 septa. In the 
green morph (A. equina equina form II) there are 100 to 160 irregularly arranged septa. Brace et al. (1979) suggest, and our own results (see below) demonstrate, that the green $A$. equina differ from other morphs in having a lower mean intertidal position and in showing a far more marked preference for cryptic habitats (e.g. under rocks). The intraspecific aggression of $A$. equina has long been known (Dalyell, 1848; Bonnin, 1964) and has been studied by various authors. However in the green morphs there are marked differences in this aggressive behaviour (Brace and Pavey, 1978; Brace et al., 1979). It has also been shown (Hall et al., 1982) that the predatory nudibranch Aeolidia papillosa is able to distinguish between green and other colour morphs of Actinia when choosing its prey.

In the present work we have used electrophoretically detectable enzyme polymorphisms to study gene flow and possible genetic differentiation between colour morphs of Actinia equina (sensu Manuel, 1981). Enzyme electrophoresis has been used by several authors to examine the taxonomic status of a variety of marine organisms (e.g. Manwell and Baker, 1963; Grasslé and Grasslé, 1976; Skibinski et al., 1978; Thorpe et al., 1978a, b; Smith and Robertson, 1981). It has previously also been used in various genetic and taxonomic studies on sea anemones (e.g. Ottaway and Kirby, 1975; Hoffmann, 1976; Shick and Lamb, 1977 ; Black and Johnson, 1979; Shick et al., 1979; Carter and Thorpe, 1981, 1982; Bucklin and Hedgecock, 1982; Orr et al., 1982). The technique has several advantages over more conventional taxonomic methods (Avise, 1974; Thorpe, 1979, 1982; Ferguson, 1980); in particular, conclusions can be reached far more rapidly and are less subject to subsequent dispute than those based solely upon morphological characters.

\section{MATERIALS AND METHODS}

Samples for enzyme electrophoresis were collected by random sampling from a rocky intertidal area at the south-west of Port Erin Bay (Isle of Man). Shore distribution data were obtained by taking samples along two $5 \mathrm{~m}$ wide transects at $0.5 \mathrm{~m}$ vertical intervals on the same shore. Two similar transects were also taken at Fleshwick Bay (about $2 \mathrm{~km}$ north of Port Erin). An additional comparative study was made of the range of microhabitats in which the Actina colour morphs were found. For this work Actinia populations on rock faces, and in rock pools, in crevices and in cryptic habitats were quantitatively assessed on the 2 shores. Before electrophoresis the Actinia collected were divided into red, brown and green colour morphs. Thirty of each colour were kept in separate tanks.

Electrophoresis was carried out using the horizontal starch gel technique (for general principles see reviews, e.g. by Harris and Hopkinson, 1978; Ferguson, 1980). Further information on procedures for Actinia is given by Carter and Thorpe (1981).

Shandon electrophoresis equipment was used. Constant voltage supplies were obtained using the Heathkit regulated high voltage power supply (Model IP 2717). Operating voltages varied with buffer schemes used and the current was set to between 30 and $50 \mathrm{~mA}$. Gels were made using $12.5 \%$ hydrolysed starch (Connaught or Sigma).

\section{RESULTS}

\section{Distribution data}

Four transects were used to estimate the distributions of the different colour morphs of Actinia equina. Two of these were from the south-west of Port Erin Bay and 2 from Fleshwick Bay. At Fleshwick the distribution of all colour morphs extended much further up the shore (presumably because this bay is more sheltered and it is also overshadowed by high cliffs) and transects were not therefore taken at the same levels as at Port Erin. Distribution data are given in Table 1 and Fig. 1. Height data are in metres vertically above chart datum. Since total numbers varied greatly between colour morphs the data are also given as the percentage found at each tidal level. To correct for differences in area of shore covered by each $0.5 \mathrm{~m}$ vertical increment figures are also given for percentage of total number of anemones of each colour morph per unit area of shore for each vertical height zone.

The differences between red and brown morphs are highly significant for the first $\left(\chi^{2}=26.7\right.$, d.f. $=4, \mathrm{P}=$ $\left.2.3 \times 10^{-5}\right)$ and second $\left(\chi^{2}=43.62\right.$, d.f. $=4, \mathrm{P}=8.0 \times$ $10^{-9}$ ) transects from Port Erin Bay, but (just) nonsignificant at the 0.05 level for the 2 Fleshwick transects $\left(\chi^{2}=9.24\right.$, d.f. $=4, \mathrm{P}=5.54 \times 10^{-2} ; \chi^{2}=6.55$. d.f. $=3, P=8.8 \times 10^{-2}$ ) treated separately. These data are far from significant if the samples from these 2 transects are pooled $\left(\chi^{2}=4.338\right.$, d.f. $=4, \mathrm{P}=0.36$ )

Differences in vertical distribution of the green Actinia compared to that of the combined figures for red and brown morphs are in each case more significant than differences between the red and brown morphs. Data from Port Erin Bay transects 1 and 2 are highly significant $\left(\chi^{2}=35.8\right.$, d.f. $=4, \mathrm{P}=3.2 \times 10^{-7}$; $\chi^{2}=84.8$, d.f. $=4, \mathrm{P}=1.1 \times 10^{-10}$ ) as they are also for Fleshwick Bay transect $1\left(\chi^{2}=16.6\right.$, d.f. $=3, P=8.5 \times$ $\left.10^{-4}\right)$. Differences over the second Fleshwick Bay transect are not quite significant $\left(\chi^{2}=5.69\right.$, d.f. $=2$, $P=5.8 \times 10^{-2}$ )

Microhabitat distribution was examined by taking 
Table 1. Actinia colour morphs. Numbers, percentages of total of that colour morph, and percentage per square metre at various tidal levels $(m)$ along transects at 4 sampling sites

\begin{tabular}{|c|c|c|c|c|c|c|c|c|c|c|c|c|}
\hline \multirow{3}{*}{$\begin{array}{l}\text { Height above } \\
\text { chart datum } \\
\text { (m) }\end{array}$} & \multicolumn{12}{|c|}{ Actinia colour morphs } \\
\hline & \multicolumn{3}{|c|}{ Red } & \multicolumn{3}{|c|}{ Brown } & \multicolumn{3}{|c|}{ Red and brown } & \multicolumn{3}{|c|}{ Green } \\
\hline & No. & $\%$ & $\% \mathrm{~m}^{-2}$ & No. & $\%$ & $\% \mathrm{~m}^{-2}$ & No. & $\%$ & $\% \mathrm{~m}^{-2}$ & No. & $\%$ & $\% \mathrm{~m}^{-2}$ \\
\hline \multicolumn{13}{|c|}{ Port Erin Bay (Transect 1) } \\
\hline $0.4-0.9$ & 58 & 10.4 & 0.19 & 50 & 14.4 & 0.26 & 108 & 11.9 & 0.21 & 19 & 10.9 & 0.19 \\
\hline $0.9-1.4$ & 208 & 37.2 & 1.60 & 122 & 35.1 & 1.51 & 330 & 36.4 & 1.57 & 88 & 50.3 & 2.16 \\
\hline $1.4-1.9$ & 117 & 20.9 & 0.98 & 109 & 31.3 & 1.47 & 226 & 24.9 & 1.17 & 39 & 22.3 & 1.04 \\
\hline $1.9-2.4$ & 74 & 13.3 & 0.76 & 36 & 10.3 & 0.59 & 110 & 12.1 & 0.69 & 29 & 16.6 & 0.95 \\
\hline $2.4-2.9$ & $\frac{102}{559}$ & 18.3 & 0.66 & $\frac{31}{348}$ & 8.9 & 0.32 & $\frac{133}{907}$ & 14.7 & 0.53 & $\frac{o}{175}$ & 0.0 & 0.00 \\
\hline \multicolumn{13}{|c|}{ Port Erin Bay (Transect 2) } \\
\hline $0.4-0.9$ & 112 & 17.7 & 0.35 & 48 & 19.7 & 0.39 & 160 & 18.2 & 0.36 & 8 & 7.0 & 0.14 \\
\hline $0.9-1.4$ & 198 & 31.3 & 1.38 & 55 & 22.5 & 0.99 & 253 & 28.8 & 1.27 & 78 & 67.8 & 2.99 \\
\hline $1.4-1.9$ & 133 & 21.0 & 1.00 & 96 & 39.3 & 1.87 & 229 & 26.1 & 1.24 & 29 & 25.2 & 1.20 \\
\hline $1.9-2.4$ & 75 & 11.8 & 0.57 & 7 & 2.9 & 0.14 & 82 & 9.4 & 0.46 & 0 & 0.0 & 0.00 \\
\hline $2.4-2.9$ & $\frac{115}{633}$ & 18.2 & 0.64 & $\frac{38}{244}$ & 15.6 & 0.55 & $\frac{153}{877}$ & 17.5 & 0.62 & $\frac{O}{115}$ & 0.0 & 0.00 \\
\hline \multicolumn{13}{|c|}{ Fleshwick Bay (Transect 1) } \\
\hline $1.6-2.1$ & 248 & 43.8 & 0.77 & 94 & 46.8 & 0.82 & 342 & 44.6 & 0.78 & 78 & 47.6 & 0.84 \\
\hline $2.1-2.6$ & 212 & 37.5 & 1.47 & 55 & 27.4 & 1.08 & 267 & 34.8 & 1.37 & 61 & 37.2 & 1.46 \\
\hline $2.6-3.1$ & 71 & 12.5 & 0.47 & 31 & 15.4 & 0.58 & 102 & 13.3 & 0.50 & 25 & 15.2 & 0.57 \\
\hline $3.1-3.6$ & 20 & 3.5 & 0.14 & 12 & 5.9 & 0.23 & 32 & 4.2 & 0.17 & 0 & 0.0 & 0.00 \\
\hline $3.6-4.1$ & $\frac{15}{566}$ & 2.7 & 0.12 & $\frac{9}{201}$ & 4.5 & 0.19 & $\frac{24}{767}$ & 3.1 & 0.13 & $\frac{0}{164}$ & 0.0 & 0.00 \\
\hline \multicolumn{13}{|c|}{ Fleshwick Bay (Transect 2) } \\
\hline $1.6-2.1$ & 108 & 44.1 & 0.84 & 66 & 51.2 & 0.98 & 174 & 46.5 & 0.89 & 45 & 61.6 & 1.17 \\
\hline $2.1-2.6$ & 80 & 32.7 & 0.86 & 47 & 36.4 & 0.96 & 127 & 33.9 & 0.89 & 17 & 23.3 & 0.61 \\
\hline $2.6-3.1$ & 45 & 18.4 & 0.62 & 12 & 9.3 & 0.32 & 57 & 15.2 & 0.52 & 9 & 12.3 & 0.42 \\
\hline $3.1-3.6$ & 11 & 4.5 & 0.21 & 4 & 3.1 & 0.15 & 15 & 4.0 & 0.20 & 2 & 2.7 & 0.13 \\
\hline $3.6-4.1$ & $\frac{1}{245}$ & 0.0 & 0.00 & $\frac{O}{129}$ & 0.0 & 0.00 & $\frac{1}{374}$ & 0.0 & 0.00 & $\frac{0}{73}$ & 0.0 & 0.00 \\
\hline
\end{tabular}

ten samples from areas each of $1 \mathrm{~m}^{2}$ (quadrats) in the mid-tidal area at the sampling locality in Port Erin Bay. All the Actinia within each quadrat were then examined and numbers of each colour morph in each microhabitat type were counted. Microhabitats were defined as being of 4 types: (a) rock pools, (b) exposed rock faces, (c) crevices, (d) cryptic environments (e.g. under rocks). Data (Table 2, Fig. 2) show a marked similarity in microhabitat choice between red and brown morphs $\left(\chi^{2}=2.1\right.$, d.f. $\left.=3, P=0.55\right)$ but very substantial and highly significant differences between these and the green morphs $\left(\chi^{2}=325.9\right.$, d.f. $=3$, $\left.\mathrm{P} \ll 10^{-10}\right)$.

\section{Enzyme variation}

Initially anemones of each of the 3 colour morphs represented in our sample (red, brown, green) were typed for 17 enzyme loci. On the basis of these results 13 of these loci Me (E.C. 1.1.1.40.), Idh (E.C. 1.1.1.42.),
Table 2. Actinia equina. Numbers of red, brown and green colour morphs found in each of 4 types of microhabitat. Data from 10 quadrats each of $1 \mathrm{~m}^{2}$ from the mid tidal area of Port Erin Bay

\begin{tabular}{|lrrrrr|}
\hline $\begin{array}{l}\text { Colour } \\
\text { morph }\end{array}$ & $\begin{array}{r}\text { Rock } \\
\text { pools }\end{array}$ & $\begin{array}{c}\text { Exposed } \\
\text { rock }\end{array}$ & $\begin{array}{c}\text { Crevices } \\
\text { Cryptic } \\
\text { environ- } \\
\text { ments }\end{array}$ & Total \\
\hline Red & 213 & 448 & 106 & 349 & 1116 \\
Brown & 98 & 254 & 56 & 182 & 590 \\
Green & 22 & 0 & 20 & 248 & 290 \\
\hline
\end{tabular}

Pgd (E.C. 1.1.1.44), Sdh (E.C. 1.1.1.140.), Gpd (E.C. 1.2.1.12.), Xod (E.C. 1.2.3.2.), Cat (E.C. 1.11.1.6.), Sod-1 (E.C. 1.15.1.1.), $C k$ (E.C. 2.7.3.2.), Alp (E.C. 3.1.3.1.), Fum (E.C. 4.2.1.1.), Pgi-1, Pgi-2 (E.C. 5.3.1.9.), were monomorphic and identical in all samples. However the remaining 4 loci gave indications of differences between green anemones and those of red and brown 

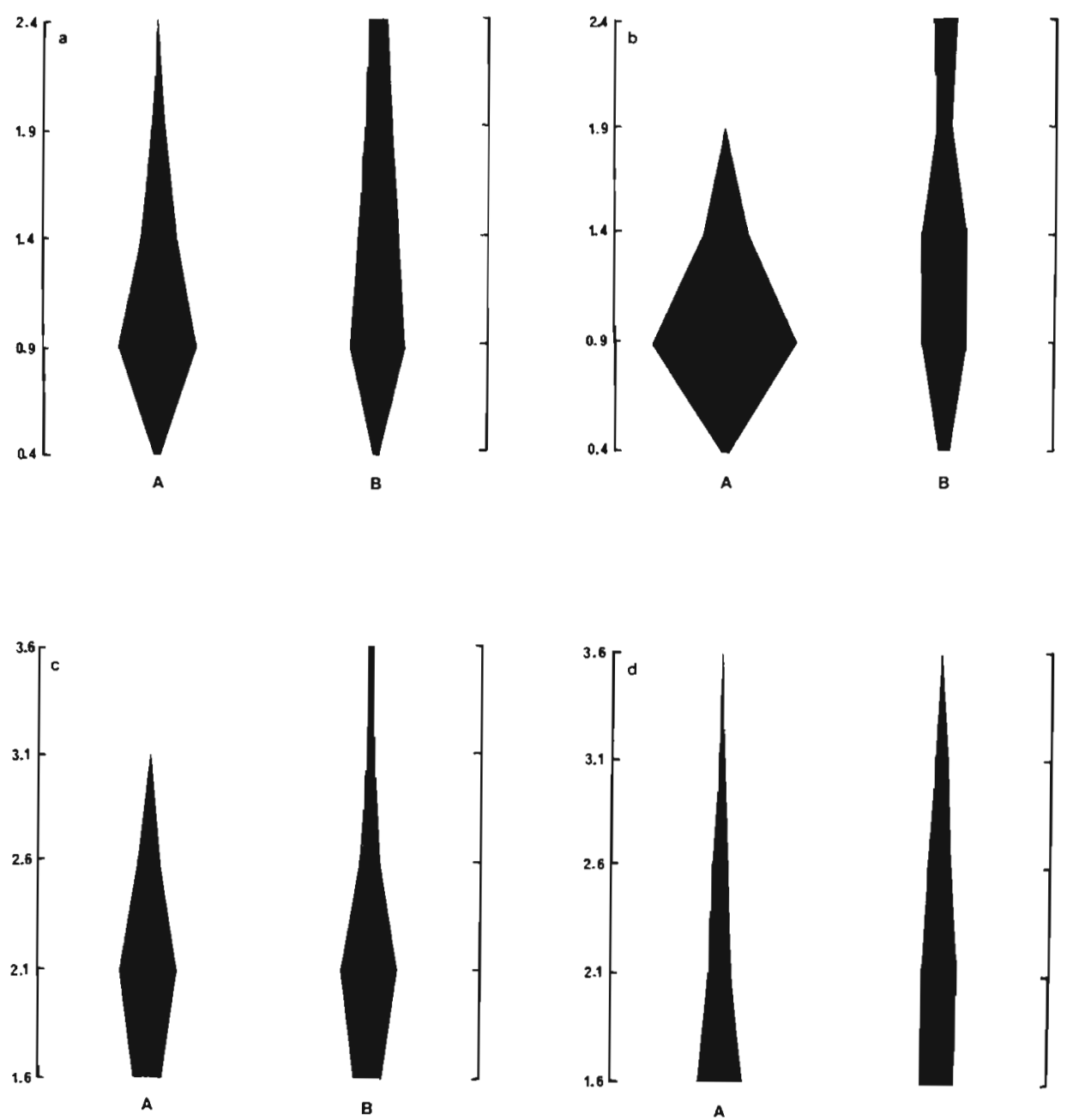

Fig. 1. Actinia equina. Relative abundance (percentage per unit area) at different tidal levels $(m)$ of $(A)$ green colour morphs and (B) other colour morphs. Transects are: (a) and (b) Port Erin Bay Transects 1 and 2; (c) and (d) Fleshwick Bay Transects 1 and 2. (For sample sizes see Table 1)

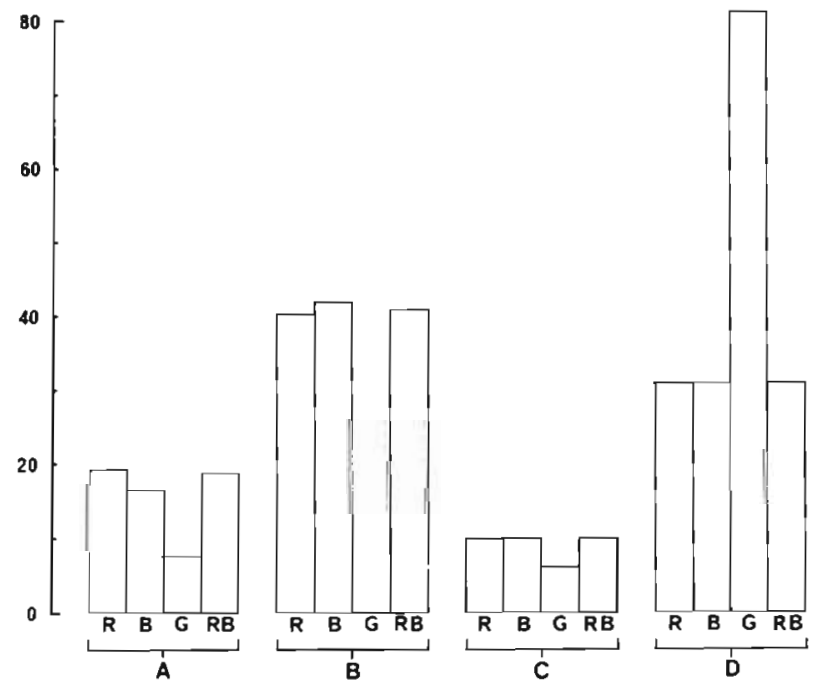

Fig. 2. Actinia equina. Percentages of each colour morph found in each of 4 types of microhabitat. Colour morphs: $R$ (red), B (brown), G (green), RB (data for red and brown morphs combined). Microhabitats: A (rock pools), B (exposed rock surfaces), $C$ (crevices), D (cryptic environments) morphs. Further specimens of each colour morph were therefore typed for each of these 4 loci.

Staining for Odh (octanol dehydrogenase, E.C. 1.1.1.1.), using 30 anemones of each colour, showed a large, consistent and repeatable difference in activity levels of this enzyme between tissue samples from the green and from the other colour morphs. There was no apparent variation in enzyme mobility. Green morph samples stained for Odh in about 15 min whilst red or brown samples took several hours. This difference indicates, in our opinion, the probability that Odh in the green morph is qualitatively different from that of other Actinia (cf. Xod differences between $A$. equina and A. fragacea, Carter and Thorpe, 1981), although the possibility of a massive quantitative difference alone cannot be eliminated entirely. A qualitative difference would provide evidence for genetic differentiation of the green morphs, whilst a quantitative difference may not do so.

The Est (esterase, E.C. 3.1.1.1.) locus showed a genetic polymorphism with 2 alleles in the red and brown 
Actinia (Fig. 3, Table 3) although the green animals were monomorphic at this locus. However the most frequent allele in the reds and browns was of the same mobility as that (apparently) fixed in the green population. The difference between the green and the other colour morphs is significant $\left(\chi^{2}=6.72\right.$, d.f. $=1, P=$ $0.0095)$ but there is no difference between reds and browns $\left(\chi^{2}=0\right.$, d.f. $\left.=1, P=1.0\right)$. The 2 banded heterozygotes for Est indicate that the enzyme structure is monomeric in Actinia. This is not unexpected since it is normally monomeric or dimeric in other organisms (Harris and Hopkinson, 1978). An esterase polymorphism in Actinia populations from Southern England has already been described by Carter and Thorp (1979) (using polyacrylamide gel electrophoresis). It is probable that the locus they have identified is the same as that described here.

Gels stained for Sod (superoxide dismutase, E.C. 1.15.1.1. = tetrazolium oxidase, TO) showed more distinct differences between the green Actinia and other colour morphs, but the genetic interpretation of the banding patterns is difficult. In several other populations of $A$. equina which have been examined (Carter

\begin{tabular}{|c|c|c|c|c|c|}
\hline $\mathbf{g}$ & $r$ & b & g & $r$ & b \\
\hline 00000 & 00000 & 00000 & 00000 & 0000 & 00000 \\
\hline & 0 & 00 & & 0 & 00 \\
\hline
\end{tabular}

Fig. 3. Actinia equina. Typical observed banding patterns for red ( $\mathrm{r}$ ), brown (b) and green ( $\mathrm{g}$ ) colour morphs on an electrophoresis gel stained for esterase

Table 3. Actinia equina. Allele frequencies at enzyme loci showing variation between green, red and brown colour morphs. $n=$ number of alleles sampled for each colour morph. Thirteen other loci showed no variation within or between morphs (Sod-1, Pgi-1, Pgi-2, Xod, Sdh, Idh, Pgd, Alp, Fum, Cat, Ck, Me, G3pd)

\begin{tabular}{|c|c|c|c|c|c|c|}
\hline \multirow[t]{2}{*}{ Locus } & \multirow[t]{2}{*}{ Allele } & \multicolumn{5}{|c|}{ Colour morph } \\
\hline & & Green & Red & Brown & $\begin{array}{l}\text { Red }+ \\
\text { brown }\end{array}$ & $n$ \\
\hline Est & $\begin{array}{l}1 \\
2\end{array}$ & $\begin{array}{l}0.00 \\
1.00\end{array}$ & $\begin{array}{l}0.16 \\
0.84\end{array}$ & $\begin{array}{l}0.16 \\
0.84\end{array}$ & $\begin{array}{l}0.16 \\
0.84\end{array}$ & 38 \\
\hline Sod-2 & $\begin{array}{l}1 \\
2\end{array}$ & $\begin{array}{l}0.57 \\
0.43\end{array}$ & $\begin{array}{l}0.12 \\
0.88\end{array}$ & $\begin{array}{l}0.18 \\
0.82\end{array}$ & $\begin{array}{l}0.15 \\
0.85\end{array}$ & 54 \\
\hline$P g m$ & $\begin{array}{l}1 \\
2 \\
3\end{array}$ & $\begin{array}{l}0.52 \\
0.02 \\
0.46\end{array}$ & $\begin{array}{l}0.77 \\
0.15 \\
0.07\end{array}$ & $\begin{array}{l}0.67 \\
0.13 \\
0.17\end{array}$ & $\begin{array}{l}0.72 \\
0.14 \\
0.12\end{array}$ & 52 \\
\hline Odh & $\begin{array}{l}1 \\
2\end{array}$ & $\begin{array}{l}1.00 \\
0.00\end{array}$ & $\begin{array}{l}0.00 \\
1.00\end{array}$ & $\begin{array}{l}0.00 \\
1.00\end{array}$ & $\begin{array}{l}0.00 \\
1.00\end{array}$ & 60 \\
\hline
\end{tabular}

and Thorpe, 1981; unpubl. own results) and also in $A$. fragacea (Carter and Thorpe, 1981) there is normally a single Sod locus. In some populations this locus is polymorphic with the heterozygotes being 3-banded (Carter and Thorpe, 1981; Fig. 1c). Three-banded heterozygotes are to be expected since Sod is normally dimeric in other organisms (Harris and Hopkinson, 1978; Ward, 1978). However in the Port Erin Bay population used here, most of the green individuals and a few of the reds and browns showed an extra zone of Sod activity as well as the usual single locus (Fig. 4).

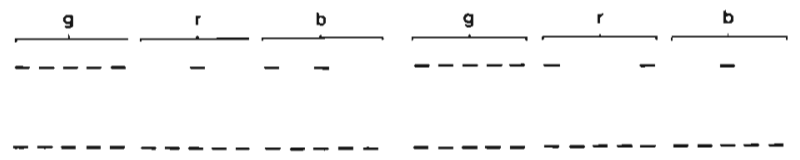

Fig. 4. Actinia equina. Typical observed banding patterns for red (r), brown (b) and green (g) colour morphs on an electrophoresis gel stained for superoxide dismutase

These additional faster bands when present were always of the same mobility and approximately the same intensity. They could always be scored unequivocally as present or absent in all samples.

The band of lower mobility appeared to represent the product of the same Sod locus found in other populations. No 3-banded heterozygotes were found and it would appear that this slower locus (Sod-1) was not polymorphic in the Port Erin Bay populations of any of the colour morphs. The relatively great difference in mobility and lack of a hybrid zone of intermediate mobility indicates that the faster zone of Sod activity, which stains only in some individuals, is not the product of a polymorphism at the Sod-1 locus. It is presumably therefore the product of a separate (Sod-2) locus. In our opinion the observed Sod banding patterns (Fig. 4) are best explained by the hypothesis that there are 2 Sod loci of which Sod-1 is monomorphic, whilst Sod-2 is polymorphic for 2 alleles, one of which has inadequate activity to give a detectable level of staining (i.e. a 'null' allele). In this case the 'null' homozygotes would not be expected to stain at all at the Sod-2 locus, whilst the heterozygotes and active homozygote would show Sod activity. The lack of a second band (the expected hybrid band of a dimeric enzyme) in the heterozygote could be explained if both 'null' and active alleles are of the same mobility (different molecular forms) (alleles) with the same electrophoretic mobility are not uncommon; see for example (Coyne and Felton, 1977; Bonhomme and Selander, 1978; Racine and Langley, 1980). Alternatively, if, as might well be the case, the inactivity of the 'null' allele results from changes in molecular confor- 
mation, then these conformational differences could well prevent the formation of the dimeric hybrid molecules. Although this hypothesis is intuitively not very attractive it is probably the most plausible explanation for the observed Sod banding patterns. It is also possible, although less likely, that there is a polymorphism for a partial deletion or partial duplication of a section of a chromosome which includes that coding for the Sod-2 locus. This is improbable since, at least in higher animals, differences in chromosome length frequently have serious effects upon the viability of hybrids between different chromosomal forms, thus leading to rapid speciation.

Allele frequencies at the Sod-2 locus (Table 3) have been calculated on the assumption that all samples showing no activity at the locus were 'null' homozygotes and that from this information the other genotype frequencies can be estimated from Hardy-Weinberg expectations. The latter assumption can probably be justified for populations of the red and brown colour morphs where possible inbreeding or asexual reproduction do not seem to greatly affect genotype frequencies, but it is more doubtful for the green morphs (see below). On these assumptions the estimated allele frequencies at the Sod-2 locus show significant differences between the green and the other colour morphs $\left(\chi^{2}=30.65\right.$, d.f. $\left.=1, \mathrm{P}=3.1 \times 10^{-8}\right)$ although there is no reason to doubt the genetic homogeneity of the red and brown morphs $\left(\chi^{2}=0.90\right.$, d.f. $\left.=1, P=0.34\right)$. Even if the interpretation of the Sod-2 banding patterns is incorrect it is still clear that there are very substantial differences at this locus between the green Actinia and the red or brown specimens. Scoring the upper zone of activity simply as present or absent still gives a highly significant difference between greens and the other colour morphs $\left(\chi^{2}=20.92\right.$, d.f. $\left.=1, P=4.8 \times 10^{-6}\right)$ but the difference between brown and red morphs is non-significant $\left(\chi^{2}=0.83\right.$, d.f. $\left.=1, \mathrm{P}=0.36\right)$.

At the Pgm (phosphoglucomutase, E.C. 2.7.5.1.) locus (Fig. 5) 3 alleles were present, but the frequen-

\begin{tabular}{|c|c|c|c|c|c|c|c|}
\hline g & $\mathrm{r}$ & b & $g$ & & $r$ & & b \\
\hline 0000 & 00000 & 00000 & 00000 & 00 & 00 & 0 & 00 \\
\hline & 0 & 00 & & & & & 0 \\
\hline 000 & & 0 & 00000 & & 00 & & 0 \\
\hline
\end{tabular}

Fig. 5. Actinia equina. Typical observed banding patterns for red ( $r$ ), brown (b) and green (g) colour morphs on an electrophoresis gel stained for phosphoglucomutase

cies (Table 3) showed highly significant differences between the green and the other colour morphs $\left(\chi^{2}=\right.$ 30.2 , d.f. $=2, \mathrm{P}=2.8 \times 10^{-7}$ ). In particular allele 2 which was at a frequency of 0.14 in the red and brown anemones was almost absent from the green population (frequency $=0.019$ ). Whilst the Pgm genotype frequencies of the reds and browns were very close to Hardy-Weinberg expectations $\left(\chi^{2}=0.20\right.$, d.f. $=1, P=$ $0.65)$ there was a large and highly significant excess of heterozygotes among the green Actinia $\left(\chi^{2}=15.51\right.$, d.f. $=1, \mathrm{P}=8.2 \times 10^{-5}$ ). There were no significant differences at this locus between the allele frequencies of the red and brown morphs $\left(\chi^{2}=2.2\right.$, d.f. $=2, \mathrm{P}=$ $0.33)$. Heterozygotes at this locus were 2-banded as would be expected since Pgm is normally monomeric (Harris and Hopkinson, 1978; Ward, 1978). Polymorphism at this locus in $A$. equina has been previously described by Orr et al. (1982).

\section{DISCUSSION}

The most salient features of this study are the general similarities between the red and brown colour morphs and the much greater differences between these and the green Actinia. The only significant differences between red and brown Actinia are in some of the data for shore distribution with tidal level. This may indicate some differences in ecological requirements between these 2 morphs. However in all cases the distribution data show a more significant difference between green Actinia and the other colour morphs than between the reds and browns (Table 1 , Fig. 1).

Comparisons of the relative abundances of the 3 colour morphs in different microhabitats (Table2, Fig. 2) show a great similarity between data for red and brown anemones $(\mathrm{P}>0.5)$, but a huge and massively significant $\left(P \ll 10^{-10}\right)$ difference between these and the green Actinia. Although very great, the ecological differences between the green and the other colour morphs provide only a somewhat equivocal indication of taxonomic differences.

A further indication of the distinctness of the green Actinia is provided by the differences between these and the other colour forms in statistical fits to HardyWeinberg equilibria. In species which are routinely outbreeding good fits are to be expected, whilst inbreeding or asexual reproduction are likely to result in significant deviations. From our data only the Pgm locus has the necessary combination of allele frequencies and sample sizes for fits to Hardy-Weinberg expectations to be tested in both the green and other colour morphs. However at this locus the green Actinia show a very highly significant deficit of homozygotes $\left(\mathrm{P}<10^{-4}\right)$ whilst the other colour forms deviated very little $(P>0.3)$. Although the red and brown morphs are known to make use of asexual reproduction (Orr et al., 1982) genotype frequencies apparently do not nor- 
mally deviate significantly from those expected on the basis of routine outbreeding. This is confirmed by previous work on various enzyme loci and populations of Actinia (Orr et al., 1982; own unpubl. results). It therefore appears that in most $A$. equina sexual reproduction by outbreeding is the major force determining genotype frequencies and asexual reproduction has little effect. In green colour morphs however this is clearly not the case and asexual reproduction is apparently of far greater importance in influencing population structure. It seems therefore that there are also important differences in reproductive strategies between green Actinia and the other colour varieties.

However, even stronger evidence of the separation of the green Actinia is provided by the results of the electrophoresis. Between sympatric populations significant differences in gene frequencies at any locus are most improbable if these populations are conspecific (and therefore interbreeding). Highly significant differences in allele frequencies at no fewer than 4 enzyme loci Odh, Est, Sod-2 and Pgm make it abundantly clear that, within a sympatric population, there is a reproductive barrier between the green and the red and brown coloured Actinia. Although there may be some gene flow between the 2 populations, to give such levels of genetic differentiation this must be at most minimal. Even very low levels of migration between populations will prevent the occurrence of differentiation whether by selection or drift (e.g. Lewontin, 1974; Falconer, 1981) unless population sizes are very small.

If there is some gene flow between green and other colours of Actinia, the green morphs may be regarded as 'semispecies' (Ayala et al., 1974; Avise, 1976) or species in statu nascendi' (Lewontin, 1974). However given the clear differences in colour, internal morphology, ecology, behaviour and reproductive methods as well as the strong evidence for a reproductive barrier between sympatric populations it becomes probable that the green Actinia are best regarded as constituting a separate species. It therefore remains to provide a specific name for the green species. A review of the older taxonomic literature (R. B. Williams, pers. comm.) suggests that the only specific name given to a green Actinia is the $A$. viridis, described by Contarini (1844) from the Adriatic Sea. However this name is not available since various late 18 th century authors had previously described under the name $A$. viridis the species currently known as Anemonia viridis (Forskall) (Manuel, 1981). Clearly there is a need for further work to establish whether there are any available (i.e. valid) specific names for green Actinia.

It is most desirable meanwhile for the green species to have a specific name and therefore we propose Actinia prasina (Latin prasinus - leek green) thus rais- ing to specific status one of the varietal names of Gosse (1860) (this is permissible for varietal names predating 1961; see Mayr, $1969 ;$ p. 362). The $A$. equina var. prasina of Gosse (1860) would appear to be at least similar to the green Actinia from the south-west of the Isle of Man. His description of var. prasina is fine leek green; tentacles the same. Pellucid'. The Isle of Man specimens used in the present work were a uniform leek green showing little colour variation. Whilst not being what might normally be described as pellucid (i.e. translucent) they were perhaps somewhat less opaque than the red or brown Actinia from the same area. The size of $A$. prasina commonly ranges up to $2 \mathrm{~cm}$ in height and $3 \mathrm{~cm}$ across the diameter of the oral disc. Exceptionally these dimensions may be as great as 4 and $5 \mathrm{~cm}$ respectively.

The differences between Actinia prasina and $A$. equina in the Isle of Man may well indicate that all green morphs of Actinia should be considered not to be conspecific with $A$. equina. However in the populations studied in the present work there is no apparent intergradation between the green animals and red or brown colour morphs. In other parts of Britain various other types of green Actinia and green-brown forms have been described (e.g. Tugwell, 1856; Gosse, 1860; Stephenson, 1935; Manuel, 1981). The specific status of some of these other greenish colour morphs is not clear and they may be conspecific with $A$. equina, $A$. prasina or possibly with neither of these. The possibility must also be borne in mind, especially during ecological studies, that cryptic speciation in Actinia may occur to a far greater extent than is clear at present (cf. bryozoans of the genus Alcyonidium: Thorpe et al., 1978a, bi Thorpe and Ryland, 1979). Apart from the present work this suggestion is supported to some extent by 2 pieces of evidence from our own unpublished data. Firstly, often very considerable, differences in gene frequencies (at enzyme loci) between geographically close, but allopatric, populations of $A$. equina indicate that gene dispersal and migration between populations in the species is very limited. This would tend to facilitate speciation. Secondly, an apparent complete separation of alleles at the $\mathrm{Pgm}$ locus between sympatric populations of two types of red colour morph found in South Wales indicates the probability that these populations are not conspecific. Although further work is needed, certain, fairly uncommon, red morphs with bright pink pedal discs appear to be reproductively isolated from other, more usual, red morphs and from the brown morphs of Actinia. At the Pgm locus both types of red morph are polymorphic but apparently with no alleles common to both. If further work indicates barriers to gene flow between other morphs in different populations it may become necessary to regard $A$. equina as a super- 
species or even a species complex with perhaps differing degrees of reproductive isolation between various populations, morphs and clones in different areas. Clearly under such circumstances the identification of 'species' would become extremely difficult and beyond the scope of conventional taxonomy.

There are several published methods for the measurement of biochemical genetic diversity between species or populations. We have used the methods of Nei (1972) and Thorpe (1979) to estimate divergence between Actinia equina and $A$. prasina. The genetic identity and genetic distance (Nei, 1972) are 0.91 and 0.09 , respectively, whilst the genetic similarity and genetic distance of Thorpe (1979) are 0.89 and 0.11 . These figures indicate little biochemical divergence with the 2 species being considerably more similar in this respect than most pairs of congeneric species (Thorpe, 1979, 1982, 1983).

There is a great shortage of genetic information on lower invertebrates and therefore estimates are also given (Table 4) of mean heterozygosity per locus and

Table 4. Actinia equina and $A$. prasina. Observed mean heterozygosity per locus and proportion of loci polymorphic. For the Sod-2 locus, where heterozygotes could not be distinguished, heterozygote frequency has been estimated on the basis of Hardy-Weinberg expectations

\begin{tabular}{|lcccc|}
\hline \multicolumn{1}{|c}{ Parameter } & A.prasina & $\begin{array}{c}\text { A.equina } \\
\text { (red and } \\
\text { brown } \\
\text { morphs) }\end{array}$ & $\begin{array}{c}\text { A. equina } \\
\text { (red } \\
\text { morphs) }\end{array}$ & $\begin{array}{c}\text { A. equina } \\
\text { (brown } \\
\text { morphs) }\end{array}$ \\
\hline $\begin{array}{l}\text { Mean } \\
\text { heterozygosity } \\
\text { Polymorphic loci }\end{array}$ & 0.068 & 0.047 & 0.067 & 0.057 \\
\hline
\end{tabular}

percentage of loci polymorphic. For this purpose loci have been considered monomorphic if the frequency of the most common allele exceeds 0.95 .

Acknowledgements. The authors are most grateful to Dr. R. B. Williams for assistance with the taxonomy and to Professors E. Naylor and J. A. Beardmore for the provision of facilities.

\section{LITERATURE CITED}

Avise, J. C. (1974). Systematic value of electrophoretic data Syst. Zool. 23: 465-481

Avise, J. C. (1976). Genetic differentiation during speciation In: Ayala, F. J. (ed.) Molecular evolution. Sinauer Associates, Sunderland, Mass., p. 106-122

Ayala, F. J., Tracey, M. L., Hedgecock, D., Richmond, R. C. (1974). Genetic differentiation during the speciation process in Drosophila. Evolution 29: 411-426
Black, R., Johnson, M. S. (1979). A sexual viviparity and population genetics of Actinia tenebrosa. Mar. Biol. 53: $27-31$

Bonhomme, F., Selander, R. K. (1978). Estimating total genic diversity in the house mouse. Biochem. Genet. 16: 287-297

Bonnin, J. P. (1964). Recherches sur la reaction d'aggression et sur la fonctionnement des acrorhages d'Actinia equina L. Bull. biol. Fr. Belg. 98: 225-250

Brace, R. C., Pavey, J. (1978). Size-dependent dominance hierarchy in the anemone Actinia equina. Nature, Lond. 273: 752-753

Brace, R. C., Pavey, J., Quicke, D. L. J. (1979). Intra-specific aggression in the colour morphs of the anemone Actinia equina: the 'convention' governing dominance ranking. Anim. Behav. 27: 553-561

Bucklin, A., Hedgecock, D. (1982). Biochemical genetic evidence for a third species of Metridium (Coelenterata: Actiniaria). Mar. Biol. 66: 1-7

Carter, M. A., Thorp, C. H. (1979). The reproduction of Actinia equina L. var, mesembryanthemum. J. mar. biol. Ass. U. K. 59: 975-1001

Carter, M. A., Thorpe, J. P. (1981). Reproductive, genetic and ecological evidence that Actinia equina var. mesembryanthemum and var. fragacea are not conspecific. J. mar. biol. Ass. U. K. 61: 71-93

Carter, M. A., Thorpe, J. P. (1982). Actinia reproduction and the species problem. Porcupine Soc. Newsletter $2: 44-45$

Cocks, W. P. (1850). Contributions to the fauna of Falmouth. Rep. Cornwall Polytech. Soc. 17: 94-95

Contarini, N. (1844). Trattato delle Attinie ed osservazioni sopra alucune di esse etc. Venice

Coyne, J. A., Felton, A. A. (1977). Genic heterogeneity at two alcohol dehydrogenase loci in Drosophila pseudoobscura and D. persimilis. Genetics 87: 285-304

Dalyell, J. C. (1848). Rare and remarkable animals of Scotland represented from living subjects: with practical observations on their nature, Vol. 2. Van Voorst, London

Falconer, D. S. (1981). Introduction to quantitative genetics. Longman, New York

Ferguson, A. (1980). Biochemical systematics and evolution. Blackie and Son, Glasgow

Gosse, P. H. (1860). A history of the British sea anemones and corals. Van Voorst, London

Grasslé, J. P., Grasslé, J. F. (1976). Sibling species in the marine pollution indicator, Capitella capitata (Polychaeta). Science, N. Y. 192: 567-569

Hall, S. J., Todd, C. D., Gordon, A. D. (1982). The influence of ingestive conditioning on the prey species selection in Aeolidia papillosa (Mollusca: Nudibranchia). J. Anim. Ecol. 51: 907-921

Harris, H. Hopkinson, D. A. (1978). Handbook of enzyme electrophoresis in human genetics. North-Holland, Amsterdam

Hoffmann, R. J. (1976). Genetics and asexual reproduction of the sea anemone Metridium senile. Biol. Bull. mar, biol. Lab., Woods Hole 151: 478-488

Lewontin, R. C. (1974). The genetic basis of evolutionary change. Columbia University Press, New York

Manuel, R. L. (1981). British Anthozoa. Linnean Society, London

Manwell, C., Baker, C. M. A. (1963). A sibling species of sea cucumber discovered by starch gel electrophoresis. Comp. Biochem. Physiol. 10: 39-53

Mayr, E. (1969). Principles of systematic zoology. McGrawHill, New York 
Milne-Edwards, H. (1857). Histoire naturelle des coralliaires ou polypes proprements dits. Paris

Nei, M. (1972). Genetic distance between natural populations. Am. Nat. 106: 283-292

Orr, J., Thorpe, J. P., Carter, M. A. (1982). Biochemical genetic confirmation of the asexual reproduction of brooded offspring in the sea anemone Actinia equina. Mar. Ecol. Prog. Ser. 7: 227-229

Ottaway, J. R., Kurby, D. C. (1975). Genetic relationships between brooding and brooded Actinia tenebrosa. Nature, Lond. 255: 221-223

Racine, R. R., Langley, C. H. (1980). Genetic heterozygosity in a natural population of Mus musculus assessed using twodimensional electrophoresis. Nature, Lond. 283: 855-857

Schmidt, H. (1971). Taxonomie, Verbreitung und Variabilität von Actinia equina Linne 1766 (Actiniaria: Anthozoa). Z. Zool. Syst. Evol. 9: 161-169

Shick, J. M., Hoffmann, R. J., Lamb, A. N. (1979). Asexual reproduction, population structure and genotype - environment interactions in sea anemones. Am. Zool. 19: 699-713

Shick, J. M., Lamb, A. N. (1977). Asexual reproduction and genetic population structure in the colonizing sea anemone Haliplanella luciae. Biol. Bull. mar. biol. Lab., Woods Hole 153: 604-617

Skibinski, D. O. F., Beardmore, J. A., Ahmad, M. (1978). Genetic aids to the study of closely related taxa of the genus Mytilus. In: Battaglia, B., Beardmore, J. A. (ed.) Marine organisms: genetics, ecology and evolution. Plenum Press, New York, p. 469-486

Smith, P. J., Robertson, D. A. (1981). Genetic evidence for two species of sprat (Sprattus) from New Zealand waters. Mar. Biol. 62: 227-233
Stephenson, T. A. (1935). The British sea anemones. Ray Society, London

Teissier, L., Teissier, G. (1930). Actinia fragacea Gosse estelle une simple varietee d'Actinia equina? Trav. Stat. Biol. Roscoff 8: 190-192

Templeton, R. (1836). A catalogue of the species of rayed animals found in Ireland. Nat. Hist. Mag. 9: 301-305

Thorpe, J. P. (1979). Enzyme variation and taxonomy: the estimation of sampling errors in measurements of interspecific genetic similarity. J. Linn. Soc. (Biol.) 11: 369-386

Thorpe, J. P. (1982). The molecular clock hypothesis: biochemical evolution, genetic differentiation and systematics. Ann. Rev. Ecol. Syst. 13: 139-168

Thorpe, J. P. (1983). Enzyme variation, genetic distance and evolutionary divergence in relation to levels of taxonomic separation. In: Oxford, G. S., Rollinson, D. (ed.) Protein polymorphism: adaptive and taxonomic significance. Systematics Association, London, p. 131-152

Thorpe, J. P., Beardmore, J. A., Ryland, J. S. (1978a). Genetic evidence for cryptic speciation in the marine bryozoan Alcyonidium gelatinosum. Mar. Biol. 49: 27-32

Thorpe, J. P., Ryland, J. S. (1979). Cryptic speciation detected by biochenical genetics in three ecologically important intertidal bryozoans. Estuar. coast. mar. Sci. 8: 395-398

Thorpe, J. P., Ryland, J. S., Beardmore, J. A. (1978b). Genetic variation and biochemical systematics in the marine bryozoan Alcyonidium mytili. Mar. Biol. 49: 343-350

Tugwell, G. (1856). A manual of sea-anemones commonly found on the English coast. London

Ward, R. D. (1978). Subunit size of enzymes and genetic heterozygosity in vertebrates. Biochem. Genet. 16: $799-810$ 